\title{
Synthesis and Characterization of Adducts of Bis(s-Alkyltrithiocarbonato)copper(II) with Oxygen Donor Ligands and Their Biological Activities
}

\author{
POOJA SHARMA, NEERUPAMA, GURPREET KOUR, \\ RAJINDER SINGH and RENU SACHAR \\ Department of Chemistry, University of Jammu, Jammu, India \\ 1285pooja@gmail.com
}

Received 5 May 2014 / Accepted 16 May 2014

\begin{abstract}
A new series of 1:2 adducts of bis(s-alkylTrithiocarbonato)copper (where alkyl= ethyl, isopropyl and tertiarybutyl) have been prepared by reacting bis(s-alkyltrithiocarbonato)copper(II) with oxygen donor ligands. The resulting adducts have been characterized by elemental analysis, molar conductance, magnetic susceptibility measurement, biological studies, IR and UV-visible spectral studies. Analytical data reveals that $\mathrm{Cu}$ (II) complexes forms 1:2 adducts. Antifungal activity of some adducts have been carried out against the fungal strain Sclerotium rolfsii. Electronic and magnetic measurements indicate distorted octahedral geometry for the 1:2 adducts of $\mathrm{Cu}(\mathrm{II})$ adducts.
\end{abstract}

Keywords: S-Alkyltrithiocarbonato, Oxygen donor ligands, Sclerotium rolfsii

\section{Introduction}

Trithiocarbonates are a versatile class of monoanionic 1,1 dithiolato systems involving sulphur donor ligands. A large number of transition metal trithiocarbonate complexes have been synthesized and characterized until now. These complexes present striking structural features and have diverse applications such as platinum group metal floatation agent, ovicidal agents, for curing and vulcanization of rubber, as a collector of sulphide ores or mineral and high pressure lubricants ${ }^{1-3}$. They have been also used as a dynamic covalent cross-linker to prepare PMMA and PSt gels via radical polymerization. These are photo responsive and can indeed undergo repeatable self healing resulting from dynamic covalent reshuffling of trithiocarbonates units. They have been also used as effective bulk sulphide collectors and effective raft agents ${ }^{4-8}$. These have been also used in the cleavage of polystyrene- $b$-poly(ethylene oxide) block copolymers, in the synthesis of a thermo responsive shell-cross linked 3-layer onion-like polymer particle with a hyper branched polyglycerol core and in the synthesis of $(\mathrm{ABCB}) \mathrm{n}$ type ternary amphiphilic multi block copolymer via poly(ethylene oxide) macro chain transfer agent ${ }^{9-11}$. In view of the potential biological activity and practical applications of the trithiocarbonates, we have reported the synthesis and characterization of 1:2 adducts of copper trithiocarbonates with ethanethiol, isopropanethiol and tertiarybutanethiol. 


\section{Experimental}

Ethanethiol, isopropanethiol, tertiarybutanethiol, carbondisulphide and sodium hydride are used as such. Metal analysis was done by the reported methods. Carbon, hydrogen and sulphur analysis were performed by microanalytical methods. Magnetic susceptibility of the complexes was recorded at room temperature by VSM technique. Molar conductivity in DMF at room temperature was measured using a digital conductivity meter Century CC 601 and a conductivity cell with a cell constant 1 . IR spectra of the complexes over the region $4000-400 \mathrm{~cm}^{-1}$ were recorded on Perkin Elemer FTIR spectrophotometer using $\mathrm{KBr}$ disc. The electronic spectra of the complexes were recorded in the range $12500-40000 \mathrm{~cm}^{-1}$ on Systronics 119 UV-Visible spectrophotometer. The antifungal activity of the complexes was tested by poisoned food technique against the pathogenic fungus, Sclerotium rolfsii. All the experiments were carried out at room temperature.

\section{Preparation of sodium salt of alkyl trithiocarbonate}

Sodium hydride $(2.3 \mathrm{~g}, 0.1 \mathrm{~mol})$ was dissolved in $100 \mathrm{~mL}$ of tetrahydrofuran. To this $4 \mathrm{~mL}$ of ethanethiol was added when a white suspension of mercaptide salt was obtained. Now carbon disulphide $(15 \mathrm{~mL})$ was added drop wise to this solution with constant stirring when a yellow coloured solution of the sodium alkyl trithiocarbonate was obtained ${ }^{12}$.

\section{Preparation of Bis(s-alkyltrithiocarbonato)copper(II)}

An aliquot of the alkyltrithiocarbonato (where alkyl = ethyl, isopropyl and tertiarybutyl) solution prepared above was added to an aqueous solution of copper(II) chloride. The mixture was immediately extracted with several portions of ether and the combined extracts were dried over anhydrous magnesium sulphate. The ether was removed under reduced pressure and shiny brown coloured complex were isolated.

Preparation of 1:2 adduct of Bis(s-alkyltrithiocarbonato)copper(II) with oxygen donor ligands

Bis(s-alkyltrithiocarbonato)copper(II) complex $(0.01$ mole) (where alkyl =ethyl, isopropyl or tertiarybutyl) were dissolved in chloroform. Now oxygen donor ligands like DMSO (0.01 mole) and HMPA ( 0.01 mole) was added to this solution with continuous stirring. There is no change in colour. This solution was then stirred on magnetic stirrer for 6-8 hours till colour changes to reddish brown. Reddish brown coloured precipitates so obtained were filtered, washed with chloroform and dried over anhydrous calcium chloride in a vacuum dessicator at room temperature.

\section{Results and Discussion}

The adducts were analyzed by various analytical and physicochemical techniques and the results shows that bis(s-alkyltrithiocarbonato)copperl(II) (where alkyl =ethyl, isopropyl and tertiarybutyl) forms 1:2 adducts with DMSO and HMPA. The analytical data (Table 2) reveals that 1:2 adduct have general formula $\mathrm{Cu}\left[\mathrm{S}_{2} \mathrm{CS}(\mathrm{R})_{2}\right]_{2} \mathrm{~L}_{2} \quad$ (where $\mathrm{L}=$ DMSO and HMPA). All the adducts are coloured and stable in air. Conductance measurements were done to ascertain the electrolytic/ non-electrolytic nature of the metal complexes. The molar conductivity values of 1:2 adducts of $\mathrm{Cu}\left[\mathrm{S}_{2} \mathrm{CS}(\mathrm{R})_{2}\right]_{2} \mathrm{~L}_{2}$ measured in $10^{-3} \mathrm{M}$ DMF solution are found to be in the range of $3.49-3.79 \mathrm{ohm}^{1} \mathrm{~cm}^{2} \mathrm{~mol}^{-1}$ (Table1). These values suggest nonelectrolytic nature of these adducts ${ }^{13,14}$. 


\section{Magnetic measurements}

The magnetic moments of all the adducts were measured at room temperature and presented in Table 1. The 1:2 adducts of bis(s-alkyltrithiocarbonato)copper(II) exhibit magnetic moment values in the range of 1.82-1.89 B.M. These values are slightly higher than the spin only value and are in accordance with distorted octahedral geometry for the 1:2 adducts ${ }^{15,16}$.

Table 1. Molar conductance and magnetic susceptibility measurement data of 1:2 adducts of bis(s-alkyltrithiocarbonato)copper(II) with oxygen donor ligands

\begin{tabular}{|c|c|c|c|c|}
\hline S.No & Name of the adduct & Colour & $\begin{array}{c}\text { Molar } \\
\text { conductance } \\
\mathrm{ohm}^{-1} \mathrm{~mol}^{-1} \mathrm{~cm}^{2} \\
\end{array}$ & $\begin{array}{l}\mu_{\text {eff }} \text { B.M. } \\
\text { at } 293 \mathrm{~K}\end{array}$ \\
\hline 1 & $\begin{array}{l}\text { Bis(s-ethyltrithiocarbonato) } \\
\text { (DMSO)copper(II) }\end{array}$ & $\begin{array}{l}\text { Reddish } \\
\text { brown }\end{array}$ & 3.65 & 1.84 \\
\hline 2 & $\begin{array}{l}\text { Bis(s-ethyltrithiocarbonato) } \\
\text { (HMPA)copper(II) }\end{array}$ & $\begin{array}{l}\text { Reddish } \\
\text { brown }\end{array}$ & 3.49 & 1.82 \\
\hline 3 & $\begin{array}{l}\text { Bis(s-isopropyltrithiocarbonato) } \\
\text { (DMSO)copper(II) }\end{array}$ & $\begin{array}{l}\text { Reddish } \\
\text { brown }\end{array}$ & 3.68 & 1.87 \\
\hline 4 & $\begin{array}{l}\text { Bis(s-isopropyltrithiocarbonato) } \\
\text { (HMPA)copper(II) }\end{array}$ & $\begin{array}{l}\text { Reddish } \\
\text { brown }\end{array}$ & 3.73 & 1.83 \\
\hline 5 & $\begin{array}{l}\text { Bis(s-tertiarybutyltrithiocarbonato) } \\
\text { (DMSO)copper(II) }\end{array}$ & $\begin{array}{l}\text { Reddish } \\
\text { brown }\end{array}$ & 3.76 & 1.89 \\
\hline 6 & $\begin{array}{l}\text { Bis(s-tertiarybutyltrithiocarbonato) } \\
\text { (HMPA)copper(II) }\end{array}$ & $\begin{array}{l}\text { Reddish } \\
\text { brown }\end{array}$ & 3.79 & 1.88 \\
\hline
\end{tabular}

Table 2. Analytical data of $1: 2$ adducts of bis(s-alkyltrithiocarbonato)copper(II) with oxygen donor ligands

\begin{tabular}{llllllllll}
\hline \multirow{2}{*}{$\begin{array}{c}\text { N } \\
\text { N }\end{array}$} & \multicolumn{1}{c}{ Name of the adduct } & \multicolumn{3}{c}{ Found, \% } & \multicolumn{5}{c}{ Calculated, \% } \\
\cline { 2 - 9 } & $\mathrm{C}$ & $\mathrm{H}$ & $\mathrm{N}$ & $\mathrm{S}$ & $\mathrm{C}$ & $\mathrm{H}$ & $\mathrm{N}$ & $\mathrm{S}$ \\
\hline 1 & $\begin{array}{l}\text { Bis(s-ethyltrithiocarbonato) } \\
\text { (DMSO)copper(II) }\end{array}$ & 23.85 & 3.94 & & 51.12 & 24.31 & 4.46 & 51.87 \\
2 & $\begin{array}{l}\text { Bis(s-ethyltrithiocarbonato) } \\
\text { (HMPA)copper(II) }\end{array}$ & 30.57 & 5.94 & 11.69 & 27.06 & 31.06 & 6.61 & 12.08 & 27.61 \\
3 & $\begin{array}{l}\text { Bis(s-isopropyltrithiocarbonato) } \\
\text { (DMSO)copper(II) }\end{array}$ & 26.97 & 4.26 & 48.54 & 27.61 & 4.99 & 49.08 \\
4 & $\begin{array}{l}\text { Bis(s-isopropyltrithiocarbonato) } \\
\text { (HMPA)copper(II) }\end{array}$ & 32.68 & 6.32 & 11.07 & 25.93 & 33.17 & 6.91 & 11.61 & 26.54 \\
5 & $\begin{array}{l}\text { Bis(s-tertiarybutyltrithiocarbonato) } \\
\text { (DMSO)copper(II) }\end{array}$ & 30.15 & 4.98 & 45.92 & 30.57 & 5.46 & 46.58 \\
6 & $\begin{array}{l}\text { Bis(s-tertiarybutyltrithiocarbonato) } \\
\text { (HMPA)copper(II) }\end{array}$ & 34.78 & 6.79 & 10.69 & 24.99 & 35.13 & 7.19 & 11.18 & 25.55 \\
\hline
\end{tabular}

\section{Infrared spectra}

The most relevant bands in the IR spectra of the adducts of $\mathrm{Cu}\left[\mathrm{S}_{2} \mathrm{CS}(\mathrm{R})_{2}\right]_{2} \cdot \mathrm{L}_{2}$ are shown in Table 3. Metal trithiocarbonate shows stretching vibrations $v C-S$ symmetrical at $752 \mathrm{~cm}^{-1}$ and 
vC---S asymmetrical appears as three bands at 940, 942 and $948 \mathrm{~cm}^{-1}$ but in adducts $v \mathrm{C}---\mathrm{S}$ appears as a single band, shifts to lower frequency $\left(833-871 \mathrm{~cm}^{-1}\right)$ and $v \mathrm{C}-\mathrm{S}$ shifts to higher frequency $\left(759-804 \mathrm{~cm}^{-1}\right)$ which supports the coordination of metal ions with the ligands by these groups, that is $v \mathrm{C}-\mathrm{S}$ and $v \mathrm{C}---\mathrm{S}^{17}$. A band of medium to strong intensity observed in the region 341-420 $\mathrm{cm}^{-1}$ may be assigned to $\mathrm{Cu}-\mathrm{S}$ stretching mode. In metal trithiocarbonate C-S-C symmetrical stretching vibration appears as weak band in the region of $600-660 \mathrm{~cm}^{-1}$ but in adducts C-S-C shows a negative ${ }^{18-20}$ shift of $30-40 \mathrm{~cm}^{-1}$.

\section{Electronic spectra}

The electronic spectral data of adducts are given in Table 3 . The spectra of 1:2 adducts were recorded in DMF. The adducts of bis(s-alkyltrithiocarbonato)copper(II) shows bands at $11595-11617,14871-14877$ and $27559-27571 \mathrm{~cm}^{-1}$ which may assigned to2B1g $\rightarrow 2 \mathrm{~A} 1 \mathrm{~g}$, $2 \mathrm{~B} 1 \mathrm{~g} \rightarrow 2 \mathrm{~B} 2 \mathrm{~g}$ and $2 \mathrm{~B} 1 \mathrm{~g} \rightarrow 2 \mathrm{Eg}$ transitions, this shows that adducts have distorted octahedral geometry ${ }^{14}$.

Table 3. Electronic and vibrational spectral data of $1: 2$ adducts of bis(s-alkyltrithiocarbonato)copper(II) with oxygen donor ligands

\begin{tabular}{|c|c|c|c|c|c|c|c|c|}
\hline $\begin{array}{l}\dot{0} \\
\dot{z}\end{array}$ & Name of the adduct & 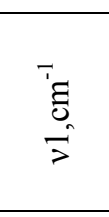 & 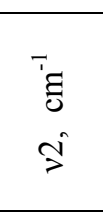 & 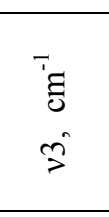 & 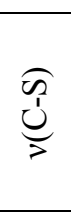 & 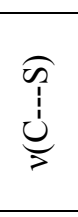 & 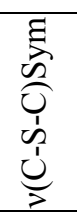 & 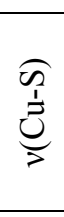 \\
\hline 1 & $\begin{array}{l}\text { Bis(s-ethyltrithiocarbonato) } \\
\text { (DMSO)copper(II) }\end{array}$ & 11617 & 14875 & 27564 & 794 & 842 & 617 & 378 \\
\hline 2 & $\begin{array}{l}\text { Bis(s-ethyltrithiocarbonato) } \\
\text { (HMPA)copper(II) }\end{array}$ & 11604 & 14871 & 27559 & 767 & 840 & 607 & 374 \\
\hline 3 & $\begin{array}{l}\text { Bis(s-isopropyltrithiocarbonato) } \\
\text { (DMSO)copper(II) }\end{array}$ & 11611 & 14882 & 27571 & 759 & 833 & 570 & 372 \\
\hline 4 & $\begin{array}{l}\text { Bis(s-isopropyltrithiocarbonato) } \\
\text { (HMPA)copper(II) }\end{array}$ & 11595 & 14877 & 27566 & 765 & 844 & 594 & 341 \\
\hline 5 & $\begin{array}{l}\text { Bis(s-tertiarybutyltrithiocarbonato) } \\
\text { (DMSO)copper(II) }\end{array}$ & 11614 & 14880 & 27569 & 804 & 842 & 621 & 399 \\
\hline 6 & $\begin{array}{l}\text { Bis(s-tertiarybutyltrithiocarbonato) } \\
\text { (HMPA)copper(II) }\end{array}$ & 11598 & 14873 & 27564 & 767 & 871 & 586 & 420 \\
\hline
\end{tabular}

\section{Biological studies}

The antifungal activity of the adducts was tested by poisoned food technique against the pathogenic fungus Sclerotium rolfsii. The linear growth of the fungus in controlled manner was recorded at different concentration of the adducts. The growth inhibition of Sclerotium rolfsii over control was calculated (Table 5). It is found that on increasing the concentration of the adducts, the colony diameter decreases and hence percent inhibition increases (Figure 1) ${ }^{21}$. The growth inhibition of Sclerotium rolfsii over control was calculated as:

$$
\% \text { Inhibition }(\mathrm{I})=\mathrm{C}-\mathrm{T} / \mathrm{C} \times 100
$$

Where $\mathrm{I}=$ percent inhibition, $\mathrm{C}=$ mean growth of fungus (in $\mathrm{mm}$ ) in control and $\mathrm{T}=$ mean growth of fungus (in $\mathrm{mm}$ ) in treatment. 
Table 5. Antifungal activities of some adducts (mean colony diameter in the control $=94 \mathrm{~mm}$ )

\begin{tabular}{llccc}
\hline S.No & Name of the adduct & $\begin{array}{c}\text { Concentration } \\
\text { ppm }\end{array}$ & $\begin{array}{c}\text { Colony } \\
\text { diameter, } \\
\text { mm }\end{array}$ & \% Inhibition \\
\hline \multirow{2}{*}{1} & Bis(s-ethyltrithiocarbonato) & 100 & 91 & 9 \\
& (DMSO)copper(II) & 200 & 80 & 60 \\
& & 400 & 31 & 92.25 \\
& & 800 & 6 & 99.25 \\
2 & Bis(s-isopropyltrithiocarbonato) & 100 & 94 & 6 \\
& (DMSO)copper(II) & 200 & 83 & 58.5 \\
& & 400 & 27 & 93.25 \\
& & 800 & 5 & 99.38 \\
3 & Bis(s-tertiarybutyltrithiocarbonato) & 100 & 97 & 3 \\
& (DMSO)copper(II) & 400 & 86 & 57 \\
& & 800 & 29 & 92.75 \\
\end{tabular}

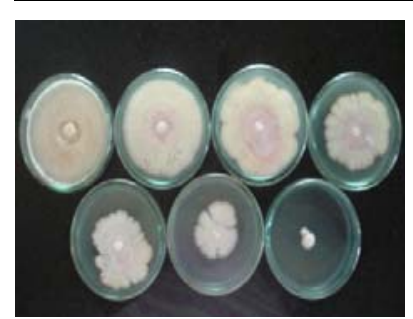

(a)

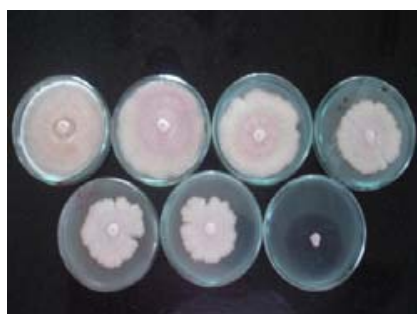

(b)

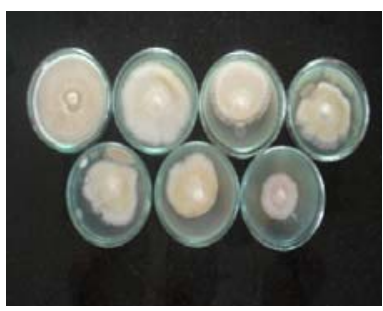

(c)

Figure 1. Antifungal activity of the adducts of (a) bis(s-thyltrithiocarbonato)(DMSO) copper(II), (b) bis(s-isopropyltrithiocarbonato)(DMSO)copper(II) and (c) bis(s-tertiarybutyltrithiocarbonato)(DMSO)copper(II)

\section{Conclusion}

On the basis of above studies it is found that 1:2 adducts of Bis(s-alkyltrithiocarbonato) copper(II) with oxygen donor ligands have distorted octahedral geometry.

\section{References}

1. Livingstone S E, Quart Rev Chem Soc., 1965, 19, 386-425; DOI:10.1039/QR9651900386

2. Coucouvanis D, Progr Inorg Chem., 1970, 11, 233.

3. Vos C F, Davidtz J C and Miller J D, J South Afr Inst Mining Metallurgy, 2007, 107, 23-28.

4. Zhishen Ge, Daoyong Chen, Jingyan Zhang, Jingyi Rao, Jun Yin, Di Wang, Xuejuan Wan, Wenfang Shi and Shiyong Liu, Polymer Chem., 2007, 45(8), 1432-1455; DOI:10.1002/pola.21914

5. Renaud Nicolay, Jun Kamada, Abagail Van Wassen and Krzysztof Matyjaszewski, Macromolecules, 2010, 43(9), 4355-4361; DOI:10.1021/ma100378r

6. Yoshifumi Amamoto, Jun Kamada, Hideyuki Otsuka, Atsushi Takahara and Krzysztof Matyjaszewski, Angewante Chemie, 2011, 123(7), 1698-1701; DOI:10.1002/ange.201003888

7. Breytenbach W, Vermaak M K G and Davidtz J C, J South Afr Inst min Metall., 2003. 
8. Roshan T A, Mayadunne, Ezio Rizzardo, John Chiefari, Julia Krstina, Graeme Moad, Almar Postma and San H Thang, Macromolecules, 2000, 33(2), 243-245; DOI:10.1021/ma991451a

9. Min Cad, Jian Qiwang, Peng Chenh Chen, Jun Ting Xu and Zhi Qiang Fan, J Polym Chem., Sci Part A: Polym Chem., 2010, 48(17), 3834-3840; DOI:10.1002/pola.24169

10. Decheng Wan, Qiang Fu and Junlian Huang, J Polym Chem., 2005, 43(22), $5652-$ 5660; DOI:10.1002/pola.21047

11. Zhongfan Jia, Chao Liu and Junlian Huang, Polymer, 2006, 47(22), 7615-7620; DOI:10.1016/j.polymer.2006.09.009

12. Andrews J M, Coucouvanis D and Fackler J P, Inorg Chem., 1972, 11(3), 493-499; DOI:10.1021/ic50109a014

13. Martin R L and Whitley A, J Chem Soc., 1958, 13, 1394-1402;

DOI:10.1039/JR9580001394

14. Geary W J, Coord Chem Rev., 1971, 7(1), 81-122; DOI:10.1016/S0010-8545(00)80009-0

15. Patel B V, Desai K and Thaker T, Synth React Inorg Met Org Nano Met Chem., 1989, 19(4), 391-412; DOI:10.1080/00945718908048078

16. Reddy P S N and Agarwala B V, Synth React Inorg Met Org Nano Met Chem., 1987, 17(6), 585-594; DOI:10.1080/00945718708059456

17. Nakamoto K, Al-Wiley Interscience, New York, $5^{\text {th }}$ Ed., 1997.

18. Sheppard N, Trans Faraday Soc., 1950, 46, 429-439; DOI:10.1039/TF9504600429

19. Rao C N R, "Chemical Applications of Infrared Spectroscopy." (Academic Press: New York London, 1963.)

20 Bellamy L J, "The Infra-red Spectra of Complex Molecules", Methuen: London 1958.

21. Nene Y L and Thapliyal P N, Fungicides in Plant Disease Control III Edn., 1993, 691. 